\title{
Organic-inorganic hybrid Sn-based perovskite photodetectors with high external quantum efficiencies and wide spectral responses from 300 to $1000 \mathrm{~nm}$
}

\author{
Yukun Wang ${ }^{1,2}$, Dezhi Yang ${ }^{1}$, Dongge $\mathrm{Ma}^{1,3^{*}}$, Dong Ha Kim², Tansir Ahamad ${ }^{3}$, \\ Saad M. Alshehri ${ }^{3}$ and Agafonv Vadim ${ }^{4}$
}

\begin{abstract}
Organic-inorganic hybrid perovskites are ideal materials for photodetection owing to their high charge carrier mobility, long charge carrier diffusion length, low dark current density and sharp absorption edge. However, a relatively small band gap $(1.6 \mathrm{eV})$ limits their photonharvesting efficiency in the near-infrared region. In the present work, we demonstrate a hybrid methylamine iodide and $\mathrm{Pb}$-Sn binary perovskite as the light absorption layer in photodetectors. Experimentally, the wavelength of photoresponse onset for the photodetectors can be extended to as great as $1,000 \mathrm{~nm}$ when the $\mathrm{Sn}$ content of the hybrid perovskite is increased to $30 \mathrm{~mol} \%$. In addition, the photodetectors exhibit a photoresponsivity of $0.39 \mathrm{~A} \mathrm{~W}^{-1}$, a specific detectivity of $7 \times 10^{12}$ Jones, a fast photoresponse with rise and decay time constants and an external quantum efficiency greater than $50 \%$ in the wavelength range of $350-900 \mathrm{~nm}$, with a maximum value of about $80 \%$ at $550 \mathrm{~nm}$.
\end{abstract}

Keywords: organic-inorganic hybrid perovskite, photodetector, external quantum efficiency, spectral response, specific detectivity

\section{INTRODUCTION}

Organic-inorganic hybrid perovskites have been considered to be one of the most promising materials for solar energy harvesting and other optoelectronic devices due to long excitation diffusion length, high charge carrier mobility, direct band gap and large absorption coefficient [1-5]. In fact, the power conversion efficiency (PCE) of these materials has increased over the past nine years from $3.8 \%$ to the current record of $22.1 \%$ [6-14]. In addition to organic-inorganic hybrid perovskites, some all-inorganic perovskites also attracted the attention of researchers $[15,16]$.

A broad community of researchers also paid attention to perovskite photodetectors [17]. Yang et al. [18] were the first to demonstrate an organic-inorganic hybrid perovskite photodetectors with an inverted device configuration in 2014. Interestingly, the inverted conjugated polymer (poly [(9,9-bis ( $3^{\prime}-(N, N$-dimethylamino) propyl)-2,7-fluorene)-alt-2,7-(9,9-dioctylfluorene)], PFN) provided an additional electric field that prevented hole injection and suppressed the dark current density. The resulting specific detectivity $\left(D^{*}\right)$ approached $10^{14}$ Jones. Huang et al. [19] also reported a device interface engineering, where, after replacing the conductive polymer composed of poly(3,4-ethylenedioxythiophene) (PEDOT) doped with poly(styrenesulfonate) (PSS), denoted as PEDOT:PSS, with N4,N4'-bis(4-(6-((3-ethyloxetan-3-yl)methoxy)hexyl)phenyl)-N4,N4'-diphenylbiphenyl-4,4'-diamine (OTPD), the highly sensitive photodetector device demonstrated a high average external quantum efficiency (EQE) approaching 90\%, a large linear dynamic range (LDR) of $94 \mathrm{~dB}$, and a short response time of $120 \mathrm{~ns}$. Analogously, Paul et al. [20] optimized the thickness of the transport layer in the

\footnotetext{
${ }^{1}$ Institute of Polymer Optoelectronic Materials and Devices, State Key Laboratory of Luminescent Materials and Devices, South China University of Technology, Guangzhou 510640, China

${ }^{2}$ Department of Chemistry and Nano Science, Ewha Womans University, 52, Ewhayeodae-gil, Seodaemun-gu, Seoul 03760, Korea

${ }^{3}$ Department of Chemistry, College of Science, King Saud University, Riyadh 11451, Kingdom of Saudi Arabia

${ }^{4}$ Moscow Institute of Physics and Technology Dolgoprudny, Moscow Region 141700, Russia

*Corresponding author (email: msdgma@scut.edu.cn)
} 
photodetector based on an organic-inorganic hybrid perovskite light absorption layer to achieve low noise, infrared (IR)-blind visibility and high $D^{*}$. For all the above discussed photodetectors, the light absorption layer was composed of $\mathrm{CH}_{3} \mathrm{NH}_{3} \mathrm{PbI}_{3}$ (or $\mathrm{CH}_{3} \mathrm{NH}_{3} \mathrm{PbI}_{3-x} \mathrm{Cl}_{x}$ ). However, due to the small band gap $(1.6 \mathrm{eV})[21,22]$, these devices provided a photoresponse onset at about $800 \mathrm{~nm}$, which hindered the efficient harvesting of photons in the near-IR (NIR) region. Therefore, the key to further enhance the performance of organic-inorganic hybrid perovskite photodetectors is to broaden the photoresponse into the NIR region. Although a photoresponse up to $950 \mathrm{~nm}$ was reported using polymer-perovskite hybrid thin films as the light absorber in our recent work [23], these photodetectors yielded only an $\mathrm{EQE}$ of $\sim 60 \%$ in the visible region of the spectrum, which is less than most organic-inorganic hybrid perovskite photodetectors. Recently, Fan et al. [24] reported lead-free perovskite photodetectors with drastically improved stability, but they showed a detectivity lower than $10^{11}$ Jones.

The present study aims to resolve this deficiency in our previous work by a hybrid $\mathrm{CH}_{3} \mathrm{NH}_{3} \mathrm{I}$ and $\mathrm{Pb}$-Sn binary perovskite with a layered structure composed of indium tin oxide (ITO), PEDOT:PSS, $\mathrm{CH}_{3} \mathrm{NH}_{3} \mathrm{~Pb}_{1-x} \mathrm{Sn}_{x} \mathrm{I}_{3}, \mathrm{C}_{60}$ and Al layers, which serves as the front contact, hole extraction, light absorption layer, electron extraction and back contact, respectively. The hybrid perovskite thin films were formed by the deposition of a mixture of tin iodide $\left(\mathrm{SnI}_{2}\right)$ with a molar content defined by $x$ and lead iodide $\left(\mathrm{PbI}_{2}\right)$ with a molar content defined by $1-x$, followed by the deposition of $\mathrm{CH}_{3} \mathrm{NH}_{3} \mathrm{I}$ [25]. The hybrid perovskite photodetector with a Sn content of $30 \mathrm{~mol} \%$ (i.e., $x=0.3$ ) provided the best photon harvesting performance with a NIR photoresponse of $1,000 \mathrm{~nm}$.

\section{EXPERIMENTAL SECTION}

$\mathrm{CH}_{3} \mathrm{NH}_{3} \mathrm{I}$ was synthesized via the reaction of $24 \mathrm{~mL}$ methylamine (33 wt.\% in ethanol; Aldrich) and $10 \mathrm{~mL}$ hydroiodic acid (57 wt.\% in water; Aladdin) in $100 \mathrm{~mL}$ ethanol in an ice bath for $2 \mathrm{~h}$ with stirring [26]. The precipitate was collected using a rotary evaporator at $50^{\circ} \mathrm{C}$ to remove the solvent, and the product was recrystallized from ethanol. The crystals were filtered and washed three times with diethyl ether, and the solid was dried at $60^{\circ} \mathrm{C}$ in a vacuum oven overnight. All other materials were purchased from commercial sources.

All photodetectors were fabricated on commercial ITO patterned glass electrode substrates. As illustrated in Fig. 1, PEDOT:PSS (Clevios ${ }^{\mathrm{TM}}$ P VP Al 4083, Heraeus) was

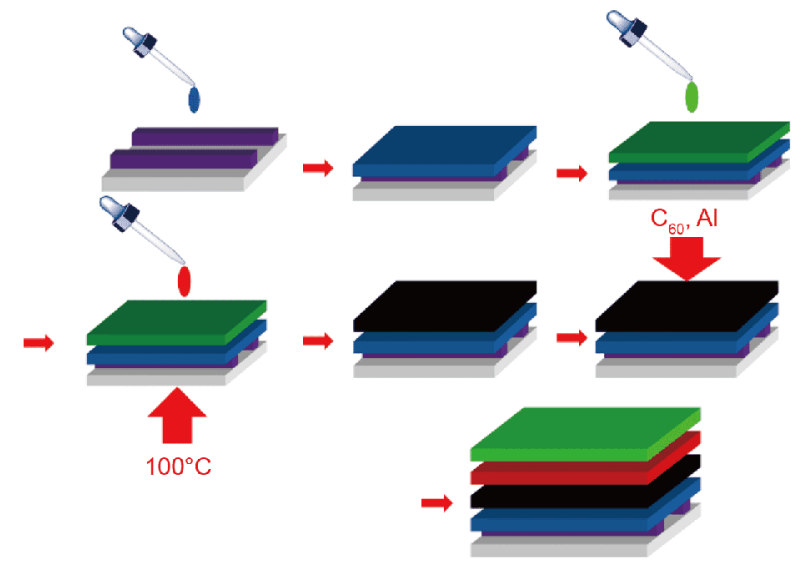

Figure 1 Schematic diagram illustrating the fabrication steps and architecture of the resulting hybrid perovskite photodetectors. PEDOT: PSS (blue) was spin-coated on the ITO side (purple) of the substrates. A mixture of $\mathrm{PbI}_{2}$ and $\mathrm{SnI}_{2}$ (green) was deposited by spin coating on the PEDOT:PSS surface using a $\left(\left[\mathrm{PbI}_{2}\right]_{1-x}+\left[\mathrm{SnI}_{2}\right]_{x}\right)$ and DMF solution. A second layer consisting of $\mathrm{CH}_{3} \mathrm{NH}_{3} \mathrm{I}$ (red) was spin-coated on the top of the $\mathrm{PbI}_{2}$ and $\mathrm{SnI}_{2}$ film, followed by annealing. $\mathrm{CH}_{3} \mathrm{NH}_{3} \mathrm{~Pb}_{1-x} \mathrm{Sn}_{x} \mathrm{I}_{3}$ layer was painted black. Then, $\mathrm{C}_{60}$ and $\mathrm{Al}$ layer were deposited by thermal evaporation. More details were shown in experimental process.

spin-coated on the ITO at 5,000 rpm for $55 \mathrm{~s}$ and cured in a furnace at $120^{\circ} \mathrm{C}$ for $20 \mathrm{~min}$ in air. $\mathrm{CH}_{3} \mathrm{NH}_{3} \mathrm{~Pb}_{1-x} \mathrm{Sn}_{x} \mathrm{I}_{3}$ layers in our photodetector devices were prepared by the interdiffusion of $\mathrm{PbI}_{2}$ and $\mathrm{SnI}_{2}$ induced by thermal annealing [24]. Briefly, a mixture of $\mathrm{PbI}_{2}$ and $\mathrm{SnI}_{2}$ was deposited by spin coating on the PEDOT:PSS surface using a $\left(\left[\mathrm{PbI}_{2}\right]_{1-x}+\left[\mathrm{SnI}_{2}\right]_{x}\right)$ and $N, N$-dimethylformamide (DMF) solution. The perovskite composition depended on $x$ of $0,0.15,0.3,0.5$ and 1.0. $\mathrm{A} \mathrm{CH}_{3} \mathrm{NH}_{3} \mathrm{I}$ layer was spin-coated on the top of the $\mathrm{PbI}_{2}$ and $\mathrm{SnI}_{2}$ film, followed by annealing at $110^{\circ} \mathrm{C}$ for $45 \mathrm{~min}$ [25]. Then, a $50 \mathrm{~nm} \mathrm{C}_{60}$ layer was evaporated on the $\mathrm{CH}_{3} \mathrm{NH}_{3} \mathrm{~Pb}_{1-x} \mathrm{Sn}_{x} \mathrm{I}_{3}$ layer surface at a rate of $0.05 \mathrm{~nm} \mathrm{~s}^{-1}$. Finally, a $100 \mathrm{~nm}$ Al layer was deposited by thermal evaporation on the $\mathrm{C}_{60}$ surface. The area of these devices is $0.08 \mathrm{~cm}^{2}$.

\section{RESULTS AND DISCUSSION}

Fig. 2a shows the crystal structure of the hybrid $\mathrm{CH}_{3} \mathrm{NH}_{3} \mathrm{~Pb}_{1-x} \mathrm{Sn}_{x} \mathrm{I}_{3}$ perovskite, where the red spheres (A), blue spheres (X) and green spheres (B) are $\mathrm{CH}_{3} \mathrm{NH}_{3}$ groups, I and $\mathrm{Pb}$ or $\mathrm{Sn}$, respectively. Theoretically, the stability of this hybrid perovskite structure can be evaluated according to a tolerance factor $\alpha$, defined as follows [27]: $\alpha=\left(r_{\mathrm{A}}+r_{\mathrm{X}}\right) /\left(2^{1 / 2}\left(r_{\mathrm{B}}+r_{\mathrm{X}}\right)\right)(1)$, where $r_{\mathrm{A}}, r_{\mathrm{B}}$ and $r_{\mathrm{X}}$ are the atomic radii of $\mathrm{A}, \mathrm{B}$ and $\mathrm{X}$, respectively. For a stable hybrid perovskite structure, $\alpha$ should be between 0.813 and 1.107 [28]. We can calculate $\alpha$ for a hybrid PbSn binary perovskite according to standard atomic radii, 

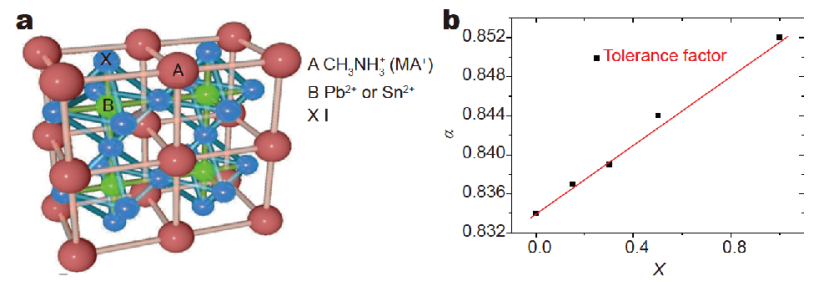

Figure 2 (a) Theoretical crystal structure of the hybrid perovskite, where the red spheres: $\mathrm{CH}_{3} \mathrm{NH}_{3}$ groups (A), blue spheres (X): I, and green spheres $(\mathrm{B}): \mathrm{Pb}$ or $\mathrm{Sn}$. (b) Tolerance factor $(\alpha)$ of the hybrid $\mathrm{Pb}-\mathrm{Sn}$ binary perovskite plotted according to Equation (1) as a function of molar Sn content $(x)$.

and plot the results according to $x$ (Fig. 2b). The $\alpha$ for $\mathrm{CH}_{3} \mathrm{NH}_{3} \mathrm{PbI}_{3}$ (i.e., $x=0$ ) is 0.834 and that for $\mathrm{CH}_{3} \mathrm{NH}_{3} \mathrm{SnI}_{3}$ (i.e., $x=1$ ) is 0.852 . Therefore, the hybrid $\mathrm{Pb}-\mathrm{Sn}$ binary perovskite is stable for all $x$. This theoretical finding is further verified experimentally by the following results.

$\mathrm{X}$-ray diffraction (XRD) patterns of $\mathrm{CH}_{3} \mathrm{NH}_{3} \mathrm{PbI}_{3}$, $\mathrm{CH}_{3} \mathrm{NH}_{3} \mathrm{~Pb}_{0.85} \mathrm{Sn}_{0.15} \mathrm{I}_{3}, \mathrm{CH}_{3} \mathrm{NH}_{3} \mathrm{~Pb}_{0.7} \mathrm{Sn}_{0.3} \mathrm{I}_{3}, \mathrm{CH}_{3} \mathrm{NH}_{3} \mathrm{~Pb}_{0.5^{-}}$ $\mathrm{Sn}_{0.5} \mathrm{I}_{3}$ and $\mathrm{CH}_{3} \mathrm{NH}_{3} \mathrm{SnI}_{3}$ hybrid perovskite films deposited on PEDOT:PSS are presented in Fig. 3a. The primary XRD peaks obtained for all of these hybrid perovskites are found at about $14^{\circ}$ and $28^{\circ}$, which are ascribed to (110) and (220) lattice planes, respectively, and lead to a tetragonal crystal structure [29]. In the optical absorption spectra (Fig. 3b), the electronic absorption edges of these perovskite thin films present an obvious shift to higher wavelengths (i.e., a red-shift) with increasing $x$. We also note that the optical absorption of the $\mathrm{CH}_{3} \mathrm{NH}_{3} \mathrm{PbI}_{3}$ film decreases rapidly around $780 \mathrm{~nm}$, while the absorption edges of all other films decrease gradually in a long-tailed fashion. After $\mathrm{Sn}$ was added into $\mathrm{Pb}$-based perovskite, the bandgap of perovskite will be shortened. Hence, perovskite thin films demonstrated narrowing optical absorption bands with the increase of Sn (Fig. 3c). These results indicate that $\mathrm{Sn}$ is helpful for broadening the hybrid perovskite photoresponse.

In Fig. 4, the surface morphologies of $\mathrm{CH}_{3} \mathrm{NH}_{3} \mathrm{PbI}_{3}$, $\mathrm{CH}_{3} \mathrm{NH}_{3} \mathrm{~Pb}_{0.85} \mathrm{Sn}_{0.15} \mathrm{I}_{3}$, and $\mathrm{CH}_{3} \mathrm{NH}_{3} \mathrm{~Pb}_{0.7} \mathrm{Sn}_{0.3} \mathrm{I}_{3}$ are very similar, while $\mathrm{CH}_{3} \mathrm{NH}_{3} \mathrm{~Pb}_{0.5} \mathrm{Sn}_{0.5} \mathrm{I}_{3}$ and $\mathrm{CH}_{3} \mathrm{NH}_{3} \mathrm{SnI}_{3}$ exhibit obvious pinholes. As found in many reports, it may be due to the rapid crystallization of Sn-based perovskite making it difficult to fabricate compact and uniform perovskite films [30].

The device structure used in this study is shown in Fig. 5a. Fig. 5b presents typical EQE spectra under a short circuit condition for all hybrid perovskite photodetectors. In the case of $x=0$, the EQE exhibits a high peak value $(\sim 85 \%)$ in the visible light region and a photoresponse onset at $\sim 800 \mathrm{~nm}$ due to its band gap of $1.6 \mathrm{eV}$, leading to a wide spectral range in the NIR region that remains unused and thus hindering the efficient photon harvesting of the photodetector. However, with increasing $x$ from 0 to 0.3 , the EQE decreases only slightly below $800 \mathrm{~nm}$, while the spectra exhibit obvious red-shifts to wavelengths greater than $800 \mathrm{~nm}$. Here, the photoresponse onset with $x=0.15$ is $\sim 900 \mathrm{~nm}$, while that with $x=0.3$ is $\sim 1,000 \mathrm{~nm}$. However, with $x=0.5$, although the photoresponse onset exceeds $1,000 \mathrm{~nm}$, the EQE in the visible light region is strongly attenuated compared with devices with lower Sn content. Moreover, the photodetector employing the $\mathrm{CH}_{3} \mathrm{NH}_{3} \mathrm{SnI}_{3}$ hybrid perovskite thin film with all $\mathrm{Pb}$ replaced by $\mathrm{Sn}$ exhibits no photoresponse [31]. This indicates that the Sn content affects the wavelength range of the photoresponse of the hybrid perovskite photodetectors, and implies that, if the Sn content is not too high, the photoresponse can be broadened. In addition, we measured the monochromatic NIR photoresponse of the two photodetector devices with $x=0.15$ and 0.3 as a function of bias voltage (Fig. 5 c). Here, we note that, at $900 \mathrm{~nm}$, the EQE of the photodetector with $x=0.3$ is about $50 \%$ greater than that with $x=0.15$. If the optical wavelength is shifted to
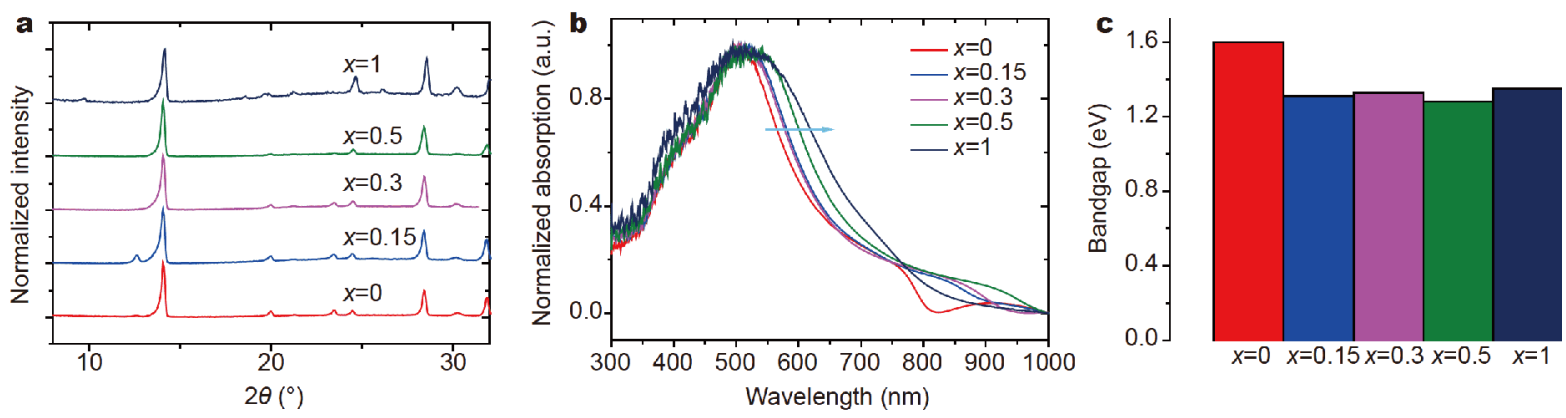

Figure 3 (a) XRD patterns, (b) optical absorption spectra and (c) energy level diagram of $\mathrm{CH}_{3} \mathrm{NH}_{3} \mathrm{PbI}_{3}(x=0), \mathrm{CH}_{3} \mathrm{NH}_{3} \mathrm{~Pb}_{0.85} \mathrm{Sn}_{0.15} \mathrm{I}_{3}(x=0.15)$, $\mathrm{CH}_{3} \mathrm{NH}_{3} \mathrm{~Pb}_{0.7} \mathrm{Sn}_{0.3} \mathrm{I}_{3}(x=0.3), \mathrm{CH}_{3} \mathrm{NH}_{3} \mathrm{~Pb}_{0.5} \mathrm{Sn}_{0.5} \mathrm{I}_{3}(x=0.5)$ and $\mathrm{CH}_{3} \mathrm{NH}_{3} \mathrm{SnI}_{3}(x=1)$ perovskite films fabricated on PEDOT:PSS. 

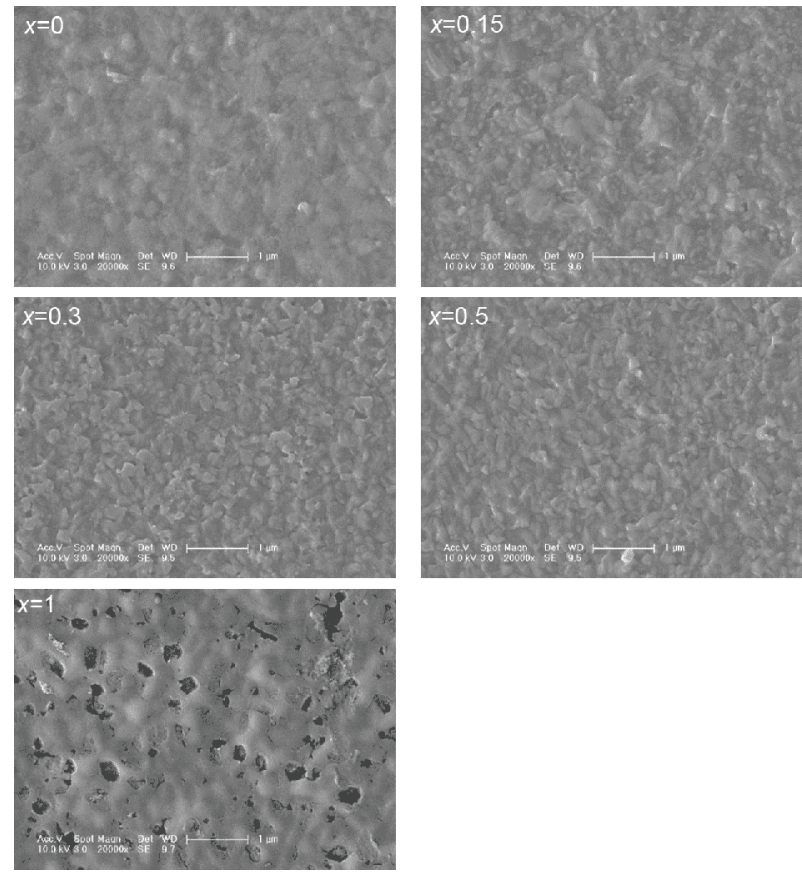

Figure 4 Scanning electron microscopy (SEM) images of $\mathrm{CH}_{3} \mathrm{NH}_{3} \mathrm{PbI}_{3}$, $\mathrm{CH}_{3} \mathrm{NH}_{3} \mathrm{~Pb}_{0.85} \mathrm{Sn}_{0.15} \mathrm{I}_{3}, \mathrm{CH}_{3} \mathrm{NH}_{3} \mathrm{~Pb}_{0.7} \mathrm{Sn}_{0.3} \mathrm{I}_{3}, \mathrm{CH}_{3} \mathrm{NH}_{3} \mathrm{~Pb}_{0.5} \mathrm{Sn}_{0.5} \mathrm{I}_{3}$ and $\mathrm{CH}_{3}-$ $\mathrm{NH}_{3} \mathrm{SnI}_{3}$ perovskite thin films on PEDOT:PSS.
$950 \mathrm{~nm}$, the EQE of the photodetector with $x=0.3$ is greater than $10 \%$, while that with $x=0.15$ is close to 0 . Accordingly, we focus on the photodetectors with $x=0$ and 0.3 in the following analyses.

The photoresponsivity $(R)$ is the ratio of the photocurrent density $\left(J_{\mathrm{ph}}\right)$ obtained by a photodetector to the incident light intensity $\left(L_{\text {light }}\right)$, and can be given as a function of EQE as follows [32,33]: $R=J_{\mathrm{ph}} / L_{\text {light }}=\mathrm{EQE} \cdot q / h v$ (2), where $q$ is the electron charge $\left(1.6 \times 10^{-19} \mathrm{C}\right), h$ is Planck's constant and $v$ is the frequency of the incident light. As such, $R$ is a good indicator of the efficiency with which photodetectors respond to optical signals. In Fig. 5d, we observe that the two photoresponse curves match well with the EQE spectra of the two photodetectors, with only slight differences in the visible light region. The $R$ for the photodetector with $x=0$ decreases in the spectral region of $390-800 \mathrm{~nm}$, while the $R$, with $x=0.3$, extends up to $1,000 \mathrm{~nm}$. In the visible light region, the maximal $R$ for the photodetectors with $x=0$ and 0.3 are $0.41 \mathrm{~A} \mathrm{~W}^{-1}$ (at 610 or $780 \mathrm{~nm}$ ) and $0.39 \mathrm{~A} \mathrm{~W}^{-1}$ (at $680 \mathrm{~nm}$ ), respectively. In the NIR spectral region of $800-1,000 \mathrm{~nm}$, the $R$ for the photodetector with $x=0.3$ presents another peak value of $0.35 \mathrm{~A} \mathrm{~W}^{-1}$ (at $890 \mathrm{~nm}$ ). The $R$ for the photodetectors with $x=0.15$ and 0.5 are
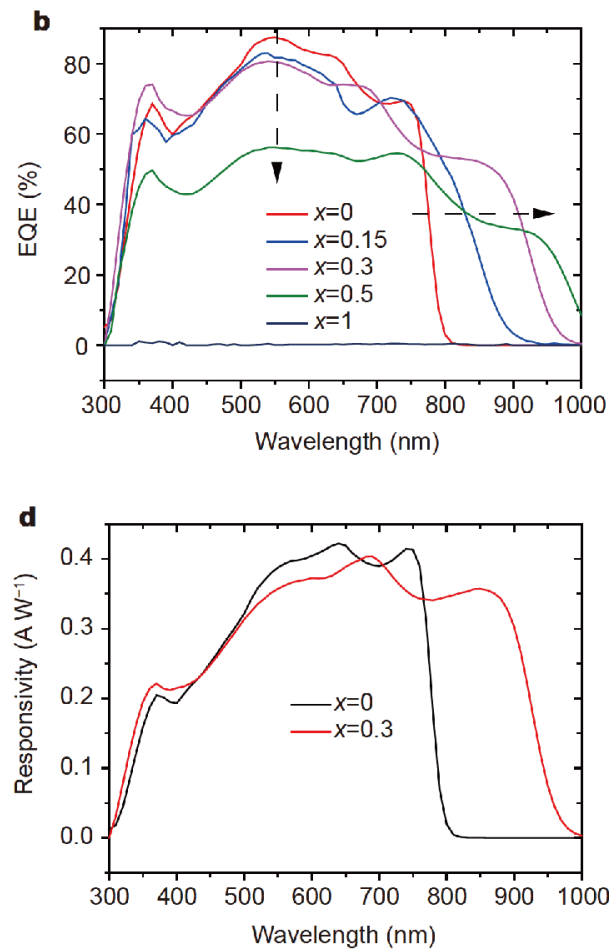

Figure 5 (a) Device structure. (b) Typical EQE spectra obtained under a short circuit condition for all hybrid perovskite photodetectors. (c) EQE spectra of hybrid perovskite photodetectors fabricated with $x=0.15$ and 0.3 at 900 and $950 \mathrm{~nm}$ (in the inset) $v s$. the bias voltage. (d) Photoresponsivity of hybrid perovskite photodetectors with $x=0$ and $0.3 v s$. wavelength from 300 to $1,000 \mathrm{~nm}$. 
shown in Fig. S1.

Fig. 6a presents the dark current density $\left(J_{d}\right)$ of the photodetectors with $x=0$ and 0.3 and the results of devices with $x=0.15$ and 0.5 are also shown in Fig. S2. Here, we find that the two hybrid perovskite photodetectors $(x=0$ and 0.3$)$ demonstrate a good rectification ratio $( \pm 1 \mathrm{~V})$. The $J_{\mathrm{d}}$ for the photodetector with $x=0.3$ is slightly less than that with $x=0$.

If, as expected, the short noise comes mainly from $J_{\mathrm{d}}$ [34], $D^{*}=R /\left(2 q J_{\mathrm{d}}\right)^{1 / 2}$ (3) [35]. Here, we can obtain $R$ and $J_{\mathrm{d}}$ from Figs $5 \mathrm{~d}$ and $6 \mathrm{a}$, respectively, and plot the calculated values of $D^{*}$ in Fig. $6 \mathrm{~b}$. The maximal $D^{*}$ obtained for the photodetector with $x=0$ is $6.5 \times 10^{12}$ Jones (at 650 or $750 \mathrm{~nm}$ ) and that with $x=0.3$ is $7 \times 10^{12}$ Jones (at $690 \mathrm{~nm}$ ). In addition, we note that the photodetector with $x=0.3$ presents another peak of $D^{*}$ of $6 \times 10^{12}$ Jones in the NIR region $(890 \mathrm{~nm})$, which exhibits a similar trend as that observed for $R$. In addition, the values of devices with $x=0.15$ and 0.5 are also shown in Fig. S3.

Generally, the photoresponse time strongly depends on charge transport and collection. As discussed previously [23], the photoresponse time is defined as the time required for the photocurrent output of a photodetector from $10 \%$ to $90 \%$ of the saturated signal. Similarly, the recovery time is defined as the time required for the photocurrent output of a photodetector from $90 \%$ to $10 \%$ of the saturated signal. Normalized transient photocurrents in Fig. 7, for the photoresponse and recovery times of the photodetectors with $x=0$ and 0.3 , clearly indicate that the photodetector with $x=0$ exhibits a shorter response time than that with $x=0.3$. However, we note that, in an actual application, the pixel size would be smaller and the response time would be expected to be much shorter [14]. The calculated bandwidths of the photodetectors fabricated with $x=0$ and 0.3 are also shown in Fig. S4. The slower response and greater bandwidth of the device with $x=0.3$ indicate that, although $\mathrm{Sn}$ can broaden the spectral response, it also
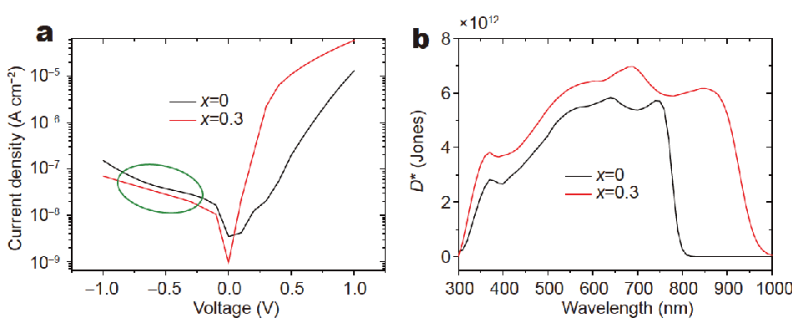

Figure 6 (a) $J_{\mathrm{d}} v s$. voltage and (b) specific detectivity $D^{*}$ calculated from Equation (3) $v s$. wavelength for the photodetectors fabricated with $x=0$ and 0.3 .

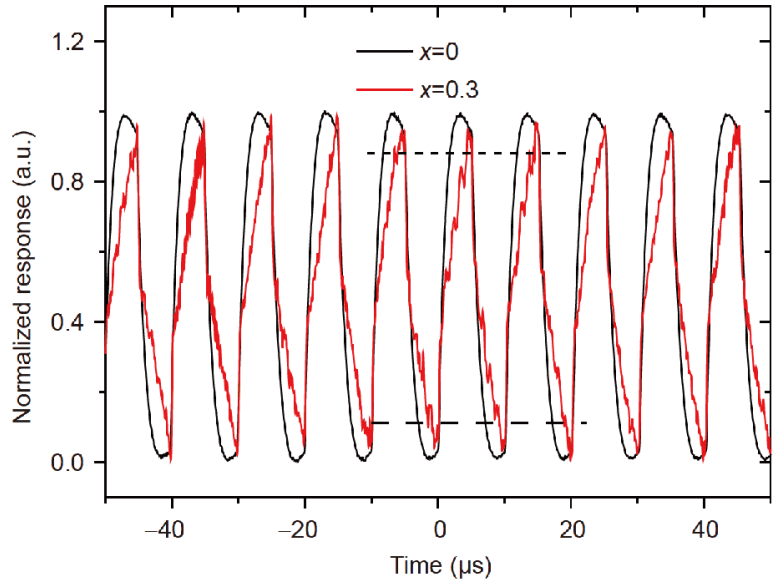

Figure 7 Photoresponse times of the photodetectors fabricated with $x=0$ and 0.3 .

indeed reduces the speed of charge transport in hybrid perovskite thin films. Moreover, we also observed the attenuation of Sn-based perovskite is faster than $\mathrm{Pb}$-based perovskite, possibly due to the oxide of $\mathrm{Sn}$ surface in air. All above results demonstrate $\mathrm{Sn}$ is an ideal material to replace $\mathrm{Pb}$ to fabricate higher performance perovskite photodetectors. However, further research is required to improve the performance and stability of Sn-based photodetectors in the near future.

\section{CONCLUSION}

We have successfully fabricated high-performance solution-processed $\mathrm{CH}_{3} \mathrm{NH}_{3} \mathrm{~Pb}_{0.7} \mathrm{Sn}_{0.3} \mathrm{I}_{3}$ photodetectors by partially replacing $\mathrm{Pb}$ with $\mathrm{Sn}$. The resulting photodetectors exhibit a photoresponse onset up to $1,000 \mathrm{~nm}$, a maximal EQE of approximately $80 \%$, a maximal $D^{*}$ greater than $7 \times 10^{12}$ Jones, and a dark current density as small as a few $\mathrm{nA} \mathrm{cm}{ }^{-2}$, which are comparable to or better than those obtained for hybrid $\mathrm{Pb}$-based perovskite photodetectors. This indicates that, with further optimization, hybrid Sn-based perovskites may replace hybrid $\mathrm{Pb}$-based perovskites for fabricating high-performance photodetectors with wide spectral response in the future.

Received 15 October 2018; accepted 26 November 2018; published online 7 December 2018

1 Lin Q, Armin A, Nagiri RCR, et al. Electro-optics of perovskite solar cells. Nat Photonics, 2015, 9: 106-112

2 Leijtens T, Stranks SD, Eperon GE, et al. Electronic properties of meso-superstructured and planar organometal halide perovskite films: charge trapping, photodoping, and carrier mobility. ACS Nano, 2014, 8: 7147-7155

3 Lim KG, Kim HB, Jeong J, et al. Boosting the power conversion efficiency of perovskite solar cells using self-organized polymeric 
hole extraction layers with high work function. Adv Mater, 2014, 26: 6461-6466

4 Frost JM, Butler KT, Brivio F, et al. Atomistic origins of highperformance in hybrid halide perovskite solar cells. Nano Lett, 2014, 14: 2584-2590

5 Xing G, Mathews N, Lim SS, et al. Low-temperature solutionprocessed wavelength-tunable perovskites for lasing. Nat Mater, 2014, 13: 476-480

6 Kojima A, Teshima K, Shirai Y, et al. Organometal halide perovskites as visible-light sensitizers for photovoltaic cells. J Am Chem Soc, 2009, 131: 6050-6051

7 Im JH, Lee CR, Lee JW, et al. 6.5\% Efficient perovskite quantumdot-sensitized solar cell. Nanoscale, 2011, 3: 4088-4093

8 Kim HS, Lee CR, Im JH, et al. Lead iodide perovskite sensitized allsolid-state submicron thin film mesoscopic solar cell with efficiency exceeding 9\%. Sci Rep, 2012, 2: 591

9 Jeon NJ, Noh JH, Kim YC, et al. Solvent engineering for highperformance inorganic-organic hybrid perovskite solar cells. Nat Mater, 2014, 13: 897-903

10 Zhou $\mathrm{H}$, Chen $\mathrm{Q}$, Li G, et al. Interface engineering of highly efficient perovskite solar cells. Science, 2014, 345: 542-546

11 Yang WS, Noh JH, Jeon NJ, et al. High-performance photovoltaic perovskite layers fabricated through intramolecular exchange. Science, 2015, 348: 1234-1237

12 Bi D, Tress W, Dar MI, et al. Efficient luminescent solar cells based on tailored mixed-cation perovskites. Sci Adv, 2016, 2: e1501170

13 Yang WS, Park BW, Jung EH, et al. Iodide management in formamidinium-lead-halide-based perovskite layers for efficient solar cells. Science, 2017, 356: 1376-1379

14 Hao F, Stoumpos CC, Cao DH, et al. Lead-free solid-state organicinorganic halide perovskite solar cells. Nat Photonics, 2014, 8: 489494

$15 \mathrm{Li} \mathrm{J}$, Xu L, Wang $\mathrm{T}$, et al. 50-Fold EQE improvement up to 6.27\% of solution-processed all-inorganic perovskite $\mathrm{CsPbBr}_{3}$ QLEDs via surface ligand density control. Adv Mater, 2017, 29: 1603885

16 Cai B, Li X, Gu Y, et al. Quantum confinement effect of twodimensional all-inorganic halide perovskites. Sci China Mater, 2017, 60: 811-818

17 Zhang X, Yang S, Zhou H, et al. Perovskite-erbium silicate nanosheet hybrid waveguide photodetectors at the near-infrared telecommunication band. Adv Mater, 2017, 29: 1604431

18 Dou L, Yang YM, You J, et al. Solution-processed hybrid perovskite photodetectors with high detectivity. Nat Commun, 2014, 5: 5404

19 Fang Y, Huang J. Resolving weak light of sub-picowatt per square centimeter by hybrid perovskite photodetectors enabled by noise reduction. Adv Mater, 2015, 27: 2804-2810

20 Lin Q, Armin A, Lyons DM, et al. Low noise, IR-blind organohalide perovskite photodiodes for visible light detection and imaging. Adv Mater, 2015, 27: 2060-2064

21 Wang $\mathrm{Y}$, Yang $\mathrm{D}$, Zhou X, et al. $\mathrm{CH}_{3} \mathrm{NH}_{3} \mathrm{PbI}_{3} / \mathrm{C}_{60}$ heterojunction photodetectors with low dark current and high detectivity. Org Electron, 2017, 42: 203-208

22 Liu Y, Hong Z, Chen Q, et al. Integrated perovskite/bulkheterojunction toward efficient solar cells. Nano Lett, 2015, 15: 662-668

23 Wang Y, Yang D, Zhou X, et al. Perovskite/polymer hybrid thin films for high external quantum efficiency photodetectors with wide spectral response from visible to near-infrared wavelengths.
Adv Opt Mater, 2017, 5: 1700213

24 Waleed A, Tavakoli MM, Gu L, et al. Lead-free perovskite nanowire array photodetectors with drastically improved stability in nanoengineering templates. Nano Lett, 2017, 17: 523-530

25 Li Y, Sun W, Yan W, et al. 50\% Sn-based planar perovskite solar cell with power conversion efficiency up to $13.6 \%$. Adv Energy Mater, 2016, 6: 1601353

26 Wang Y, Yang D, Zhou X, et al. Vapour-assisted multi-functional perovskite thin films for solar cells and photodetectors. J Mater Chem C, 2016, 4: 7415-7419

27 Kieslich G, Sun S, Cheetham AK. Solid-state principles applied to organic-inorganic perovskites: new tricks for an old dog. Chem Sci, 2014, 5: 4712-4715

28 Zhao Y, Zhu K. Organic-inorganic hybrid lead halide perovskites for optoelectronic and electronic applications. Chem Soc Rev, 2016, 45: 655-689

29 Chen Q, Zhou H, Hong Z, et al. Planar heterojunction perovskite solar cells via vapor-assisted solution process. J Am Chem Soc, 2014, 136: 622-625

30 Liao W, Zhao D, Yu Y, et al. Lead-free inverted planar formamidinium tin triiodide perovskite solar cells achieving power conversion efficiencies up to $6.22 \%$. Adv Mater, 2016, 28: 9333 9340

31 Ogomi Y, Morita A, Tsukamoto S, et al. $\mathrm{CH}_{3} \mathrm{NH}_{3} \mathrm{Sn}_{x} \mathrm{~Pb}_{(1-x)} \mathrm{I}_{3}$ perovskite solar cells covering up to $1060 \mathrm{~nm}$. J Phys Chem Lett, 2014, 5: 1004-1011

32 Qi J, Han J, Zhou X, et al. Optimization of broad-response and high-detectivity polymer photodetectors by bandgap engineering of weak donor-strong acceptor polymers. Macromolecules, 2015, 48: 3941-3948

33 Han J, Qi J, Zheng X, et al. Low-bandgap donor-acceptor polymers for photodetectors with photoresponsivity from $300 \mathrm{~nm}$ to 1600 nm. J Mater Chem C, 2017, 5: 159-165

34 Gong X, Tong M, Xia Y, et al. High-detectivity polymer photodetectors with spectral response from $300 \mathrm{~nm}$ to $1450 \mathrm{~nm}$. Science, 2009, 325: 1665-1667

35 Zhou X, Yang D, Ma D. Extremely low dark current, high responsivity, all-polymer photodetectors with spectral response from $300 \mathrm{~nm}$ to $1000 \mathrm{~nm}$. Adv Opt Mater, 2015, 3: 1570-1576

Acknowledgements The authors gratefully acknowledge the International Cooperation Foundation of China (2015DFR10700), the National Natural Science Foundation of China (51403203) for the support of this research. Prof. Ma D extends his appreciation to the Distinguished Scientist Fellowship Program (DSFP) at King Saud University, Riyadh, Kingdom of Saudi Arabia for financial support. Prof. Agafonov Vadim thanks the support of the Russian Ministry of Education and Science state assignment (3.3197.2017/ПЧ).

Author contributions Wang Y prepared the figures and wrote the paper. Ma D provided the overall concept and revised manuscript. Yang D, Kim DH, Ahamad T, Alshehri SM and Vadim A classified and analyzed the reference papers. All authors participated in the discussion.

Conflict of interest The authors declare no conflict of interest.

Supplementary information Supporting data are available in the online version of the paper. 

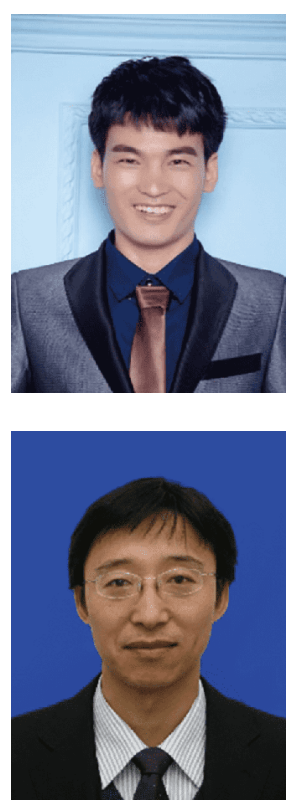

Yukun Wang received his BE degree in microelectronics from the College of Electronic Science and Engineering, Jilin University in 2013 and then joined in Prof. Dongge Ma group at Changchun Institute of Applied Chemistry, Chinese Academy of Sciences (CAS), where he obtained his PhD degree in polymer chemistry and physics in 2018. Currently, he is doing his postdoctoral research at Ewha Womans University (South Korea). His research interest includes Pb-based and $\mathrm{Pb}$-free perovskite devices (solar cells and photodetectors).
Dongge Ma studied semiconductor device physics at Liaoning University and Jilin University (China), where he received his BSc in 1989 and PhD in 1995, respectively. After additional years as a visiting professor and research fellow in the University Federal do Paranal, Brazil, and Durham University and St. Andrews University, UK, he joined Changchun Institute of Applied Chemistry, CAS, as a professor in 2001. His research interest includes the study of organic optoelectronic devices, including organic light-emitting diodes, organic photovoltaic cells and detectors, metal-based organic transistors, organic lasers, organic/inorganic hybrid perovskite devices and the physics process in these semiconductors.

\title{
具有高外量子效率和宽光谱(300 1000 nm)响应的有机-无机杂化锡基钻钦矿光电探测器
}

\author{
王玉坤 ${ }^{1,2}$, 杨德志 ${ }^{1}$,马东阁 ${ }^{1,3^{*}}$, 金东海 ${ }^{2}$, Tansir Ahamad $^{3}$, Saad M. Alshehri ${ }^{3}$, Agafonv Vadim ${ }^{4}$
}

摘要 有机-无机杂化钲钛矿材料具有载流子迁移率高、扩散长度长、暗电流密度低、吸收边缘锋利等优点, 因而成为用于光电探测的理 想材料. 但是, 相对较小的带隙 $(1.6 \mathrm{eV})$ 限制了这些材料在近红外区的光子捕获效率. 本研究中, 我们利用碘甲胺和铅-锡二元钻钠矿作为探 测器的光吸收层, 导电聚合物和富勒烯作为空穴和电子传输层, 铟锡氧化物和铝作为阳极和阴极制备了光电探测器件. 实验结果表明, 当 锡的含量达到 $30 \%$ 时, 探测器的光谱响应拓宽到 $1000 \mathrm{~nm}$. 此外, 我们制备的探测器的光谱响应度达到 $0.39 \mathrm{~A} \mathrm{~W}^{-1}$, 归一化探测率达到 $7 \times 10^{12}$ Jones. 器件的外量子效率在 350 到 $900 \mathrm{~nm}$ 范围内, 均超过 $50 \%$, 在 $550 \mathrm{~nm}$ 处取得最大值, 超过 $80 \%$. 